\title{
W ZMIERZCHAJĄCYM OGRODZIE. UTOPIA I PRAKTYKA SPOŁECZNA VASCO DE QUIROGI W NOWYM ŚWIECIE'
}

\author{
Mieczysław Jagłowski (ㄱ) http://orcid.org/0000-0001-6548-8324 \\ Uniwersytet Warmińsko-Mazurski w Olsztynie
}

\section{ABSTRACT \\ IN THE DARKENING GARDEN. UTOPIA AND SOCIAL PRACTICE OF VASCO DE QUIROGA IN THE NEW WORLD}

The article concerns the activities of Vasco de Quiroga (1470-1565), a social reformer who, in the reality of the Spanish colonial expansion in the New World, made a pioneering, successful attempt to establish autonomous republics of indigenous peoples. With regard to his initiatives, commentators expressed both recognition and disapproval. We are convinced that the divergence between these assessments was often due to insufficient account of the socio-historical context of the groundbreaking work of the Spanish reformer. In order to make a fair assessment of it, we present the social and political determinants of Quiroga's actions, and on the basis of the findings we engage in a polemic with the critical appraisals of his accomplishments. In the final remarks, we emphasize the magnitude of Quiroga's achievements, including their influence on the change of Western attitudes towards slavery.

Key words: Vasco de Quiroga, New World, colonialism, slavery, utopia, "repúblicas del hospital," postcolonial critique.

Słowa kluczowe: Vasco de Quiroga, Nowy Świat, kolonializm, niewolnictwo, utopia, ,republiki-szpitale", krytyka postkolonialna.

Odkrywcy Nowego Świata oraz ci, którzy tam po nich przybyli, byli oczarowani pięknem przyrody i szlachetnością jego mieszkańców. Zachwycali się szczęśliwym życiem tamtejszych ludów, ich beztroską, brakiem praw i sędziów, miar, wag

1 Artykuł napisano w ramach grantu OPUS 14 Narodowego Centrum Nauki, nr 2017/27/B/ HS1/00234. 
i pieniędzy, chciwości, zazdrości i przemocy². Ludy te zdawały się pielęgnować cnoty, o których zapomniano na Starym Kontynencie. Odkrywane wówczas na nowo dzieła antycznych filozofów i marzycieli o doskonałym życiu (Platona, Wirgiliusza czy Lukiana z Samosat) ${ }^{3}$ oraz lektura biblijnych proroków (zwłaszcza Izajasza i Daniela) rozbudzały nadzieje na rychłe nadejście bezgrzesznych czasów, gdy wilk $\mathrm{z}$ barankiem będą się pasły na tej samej łące, w pobliżu lwa pożywiającego się sło$\mathrm{mą}^{4}$ - już nie w starej, zepsutej Europie, lecz w Nowym Świecie. Krzysztof Kolumb, któremu najpierw zdawało się, że przybył do ziemskiego raju, już po kilku dniach otrząsnął się z tego afektu i zaczął myśleć o zaprzęgnięciu miejscowych ludzi do pracy. Kiedy po odkrywcach na nowych ziemiach pojawili się konkwistadorzy, ta myśl admirała wpłynęła na ich postawę wobec miejscowych ludów tak przemożnie, że niedługo później Bartolomé de las Casas (1484-1566), uczestnik i świadek podboju Ameryki, stwierdził, że raj został unicestwiony, a jego mieszkańcy wyniszczeni.

Jednym z pierwszych, którzy podjęli próbę uratowania ocalałych z podboju, był Vasco de Quiroga y Mendieta (1470-1565). Przybył on do części Nowego Świata należącej wcześniej do królestwa Azteków, wówczas nazywanej już Nową Hiszpanią. W 1521 roku ziemie te zostały podbite przez oddziały Hernána Cortésa (1485-1547). Hiszpański monarcha Karol V (panował w latach 1516-1556), kierując się troską o sprawiedliwe relacje między dawnymi a nowymi mieszkańcami Nowej Hiszpanii, w 1527 roku powołał sąd (Audiencia y Cancillería Real de México, znany też pod nazwą Primera Audiencia) $)^{5}$, mianując na jego przewodniczącego Nuño Beltrána de Guzmána (1500-1550). Guzmán sprzeniewierzył się jednak swej misji. Powodowany chciwością, przez dwa lata brutalnie pustoszył raz już podbity kraj w poszukiwaniu złota, mordując i torturując miejscową ludność oraz sprzedając tysiące Indian w niewolę. W 1530 roku cesarz rozwiązał Primera Audiencia i powołał nowy sąd (Segunda Audiencia, 1530-1535) i nowych sędziów (oidores) ${ }^{6}$, wśród których

2 P.M. D'Anghiera, De orbe novo, the Eight Decades of Peter Martyr d'Anghera, vol. 1, New York-London 1912, s. 79; F. Cantú, América y utopía en el siglo XVI, „Cuadernos de la Historia Moderna. Anejos" 2002, nr 1, s. 57-58.

3 J.M. Camacho Rojo, P.P. Fuentes González, El mito clásico en los historiadores de Indias [w:] Homenaje a la Profesora María Luisa Picklesimer (In memoriam), eds. M.N. Muñoz Martín, J.A. Sánchez, Coimbra 2012, s. 41-67.

4 T.S. Paniótova, Orígenes clásicos y autóctonos de la utopía en América Latina, ,Revista Iberoamericana de Autogestión y Acción Comunal” 2012, no. 60, s. 149.

5 Zadaniem ustanawianych przez hiszpańską Koronę Reales Audiencias był nadzór nad wymiarem sprawiedliwości na podległych jej terenach. Pierwszą z nich ustanowiono w $1371 \mathrm{r}$. w Valladolid (Real Audiencia y Chancillería de Valladolid). Pierwsza Audiencia w podbitej przez Hiszpanów Ameryce powstała w Santo Domingo (La Española), powołana w 1511 r. przez Diega Kolumba, gubernatora tej wyspy. W Ameryce, na terenach podległych hiszpańskiej Koronie, Reales Audiencias nadzorowały wdrażanie i przestrzeganie prawa oraz miały zapewnić prawną ochronę miejscowej ludności. Z czasem, w XVIII w., uzyskały one status najwyższych trybunałów apelacyjnych. Były uznawane za instytucje reprezentujące hiszpańskiego monarchę (dysponowały pieczęcią królewską), wypełniały funkcje sądownicze, administracyjne i polityczne.

6 Sędziowie będący członkami Reales Audiencias byli nazywani oidores (dosłownie: ,słuchaczami”). Nazwa ta wywodzi się z obowiązku wysłuchiwania (oir) przez nich stron procesu sądowego (apelacyjnego). 
znalazł się Vasco de Quiroga ${ }^{7}$. Na to stanowisko nadawał się znakomicie, wcześniej bowiem przebywał w podbitym w 1509 roku przez Hiszpanię Oranie (dzisiaj Algieria) jako Juez de Residencia, czyli audytor oceniający miejscowych sędziów pod względem zgodności wydanych przez nich wyroków (zwłaszcza tych, które zainteresowane strony uznawały za niesprawiedliwe) z przepisami hiszpańskiego prawa, naprawiając krzywdy wyrządzone tamtejszej ludności przez jego poprzednika. Pozostał w Nowej Hiszpanii do końca życia, od 1536 roku jako biskup diecezji Michoacán.

Celem artykułu jest przedstawienie prekursorskich dokonań Vasco de Quirogi zarówno w rewindykacji praw Indian do wolności, jak i w procesie rekonstrukcji życia społecznego w podbitej i kolonizowanej przez Hiszpanów Ameryce. Artykuł składa się z trzech części. W pierwszej zostaną przedstawione działania Quirogi zmierzające do ustanowienia autonomicznych republik indiańskich. Druga zarysowuje tło jego działalności, jakie stanowiły podjęte później przez hiszpańską Koronę poczynania, zmierzające do uformowania i narzucenia nowej struktury społecznej autochtonicznym ludom oraz wprowadzenia nowych zasad życia społecznego. Artykuł zamyka podsumowanie w formie uwag dotyczących współczesnej oceny dzieła Quirogi, dokonywanych zwłaszcza przez przedstawicieli krytyki postkolonialnej.

\section{UTOPIA SPEŁNIONA: INDIAŃSKIE REPUBLIKI VASCO DE QUIROGI}

Przybywając do Nowego Świata, Quiroga konstatował, że Hiszpanie, zabijając i zmuszając do pracy w kopalniach miejscową ludność, pozostawili rzesze sierot „tak biednych, że muszą chodzić po ulicach w poszukiwaniu pożywienia, jakie daje się wieprzom i psom"s, że zniszczyli złotą epokę (edad de oro, edad dorada, aquella edad dorada primera), tak iż „twarz człowieka, który został stworzony na podobieństwo Boga, zmieniła się na tej ziemi przez nasze grzechy nie w maskę głupców, lecz chciwców, którzy są gorsi niż tamci i bardziej od nich szkodliwi"”. Natychmiast po przybyciu podjął też myśl o potrzebie ochrony miejscowej ludności, na co wskazuje jego list (Carta al Consejo) skierowany w 1531 roku do Rady Indii (El Real y Supremo Consejo de Indias). Prosił w nim o przywrócenie wolności Indianom, którzy nie popełniwszy żadnych zbrodni, zostali pochwyceni i zmuszeni do pracy. Był przekonany, że nie istnieją prawne podstawy pozwalające niewolić miejscową ludność (powtarzał: „nie są oni bardziej niewolnikami niż ja ani ja bardziej wolnym i godnym niż oni”"10). W Carta al Consejo Quiroga przedstawiał także propozycję zagospodarowania przez Indian

7 J.A. de 1a Torre Range1, Tradición hispanoamericana de los derechos humanos. El aporte de dos jueces: Quiroga y Zorita [w:] Memoria. XVIII Encuentro Nacional de Investigadores del Pensamiento Novohispano. Filosofia y pensamiento político, ed. A. Sánchez Flores, San Luis Potosi 2005, s. $660-663$.

${ }^{8}$ V. de Quiroga, Carta al Consejo del licenciado Quiroga [w:] Don Vasco de Quiroga. Pensamiento jurídico. Antología, eds. R. Aguayo Spencer, J.L. Soberanes, México 1986, s. 77.

9 Ibidem, s. 168.

10 Ibidem, s. 113, 181. 
ziem niezajętych przez hiszpańskich kolonizatorów oraz postulował ustanowienie na nich oddzielnych „republik”, w których podlegaliby „świętym i dobrym katolickim zarządzeniom" "li oraz żyli pod nadzorem zakonników aż do czasu, gdy cnota stanie się ich trwałym nawykiem. Argumentował, że takie rozwiązanie jest niezbędne, by Indianie zupełnie nie wyginęli, by ich chronić przed przemocą, niesprawiedliwością oraz zniszczeniem ich obyczajów, zachowujących szlachetną czystość właściwą ludzkości w początkach jej istnienia (w „złotej epoce”). Ważnym argumentem była dla Quirogi także potrzeba ewangelizacji miejscowej ludności. Był on przekonany, że Kościół ma szansę funkcjonować wśród Indian tak, jak w epoce apostolskiej. Pisał, że Indianie w sposób spontaniczny są chrześcijanami (cristianos ingenuos ${ }^{12}$ ) praktykującymi cnoty pokory, cierpliwości i posłuszeństwa oraz wykazują brak zainteresowania dobrami doczesnymi. Wydawało mu się, że „brakuje jedynie pouczenia ich o wierze i doktrynie chrześcijańskiej, by stali się doskonałymi i prawdziwymi chrześcijanami”"13 - takimi, jakimi byli apostołowie.

Ideę indiańskich republik Quiroga rozwijał i konkretyzował w Información en derecho del licenciado Quiroga sobre algunas provisiones del Real Consejo de Indias (1535), skierowanej do cesarza Karola V. Według jego projektu indiańska ludność miałaby żyć w autonomicznych osiedlach, zorganizowanych i zarządzanych zgodnie z miejscowymi prawami, tradycjami i obyczajami, które określał mianem „republik-szpitali" (repúblicas de hospital) ${ }^{14}$. Jak wyjaśnia Abarca Pérez:

w epoce Quirogi termin szpital (hospital) jeszcze nie oderwał się od swojego łacińskiego źródła, pochodząc od hospes, gościa, kogoś przybywającego z zewnątrz, kto otrzymuje gościnę, to znaczy dach nad głową; był wówczas także żywy średniowieczny zwyczaj nazywania instytucji dobroczynnych ogólnym mianem szpitali. Don Vasco przywołuje tę nazwę, która jednoczy zarówno ideę szpitala w węższym sensie, jak i małego państwa czy „republiki szpitalnej”, do której przyjmuje się i leczy w niej każdego potrzebującego, która zarazem służy za podstawę wykreowania związku rodzin w formie osiedla ${ }^{15}$.

Ponadto w owej epoce szpitale były na Zachodzie traktowane jak instytucje powołane do praktykowania chrześcijańskiego miłosierdzia. W zakres opieki szpitalnej wchodziło wówczas nie tylko leczenie chorób cielesnych, lecz także opieka duchowa nad chorymi, którą pojmowano jako posługę religijną. Ta idea szpitala zobowiązywała do unormowania jego wewnętrznego życia na wzór zasad klasztornych. „W ten sposób szpital przemieniał się także w pewien rodzaj klasztoru, którego przestrzeń powinna mieć strukturę sprzyjającą jak najlepszemu praktykowaniu »reguły

11 Ibidem, s. 76; V. de Quiroga, Información en derecho del licenciado Quiroga sobre algunas provisiones del Real Consejo de Indias [w:] Don Vasco de Quiroga. Pensamiento jurídico, s. 99-100, $111-112,118$.

12 V. de Quiroga, Información..., s. 168.

13 Ibidem, s. 196, V. de Quiroga, Carta.., s. 76.

14 V. de Quiroga, Información..., s. 114-116; J.C. Álvarez Morán, De utopía a topía: la obra de don Vasco de Quiroga en la Nueva España, „Diario de Campo” 2011, nr 3, s. 62.

15 A.J. A barca Pérez, Hospital-pueblo, expresión concreta del humanismo quiroguiano [w:] Memoria. XVIII Encuentro Nacional de Investigadores del Pensamiento Novohispano. Filosofia y pensamiento político, ed. A. Sánchez Flores, San Luis Potosi 2005, s. 560-561. 
szpitalnej «"16. Koncepcja szpitala jako instytucji charytatywnej, ale także sprzyjającej katechizacji, została przeniesiona do Nowego Świata. Związano z nią ponadto ideę dobrej i skutecznej organizacji życia społecznego autochtonów. W ten sposób „szpital przekształca się w [...] małe miasteczko, założone w celu umożliwienia życia jego mieszkańcom"17.

Na zakupionych przez siebie terenach Quiroga założył dwa miasteczka - Santa Fe de los Altos, w pobliżu stolicy Meksyku (1532), oraz Santa Fe de la Laguna, w diecezji Michoacán (1533). Szczegółowe zasady funkcjonowania swoich „republik-szpitali” (repúblicas del hospital) wyłożył on w Reglas y ordenanzas para el gobierno de los hospitales de Santa Fe de México y de Michoacán, piśmie mającym charakter konstytucji obu wspólnot. Przewodnikiem w formułowaniu tych zasad było dla Quirogi dziełko Tomasza Morusa (1478-1535) ${ }^{18}$ opublikowane w 1516 roku jako Libellus vere aureus nec minus salutaris quam festivus de optimo reip. statu deq; nova insula Utopia ${ }^{19}$, znajdujące się w księgozbiorze biskupa Meksyku, Juana de Zumárragi $(1468-1548)^{20}$. Quiroga nie usiłował wprowadzać wszystkich rozwiązań społecznych przedstawionych przez Morusa. Kierując się względami praktycznymi, przyjął tylko te, które uznał za odpowiednie dla indiańskich społeczności. W szczególności

16 F.J. Pizarro Gómez, La fundación de hospitales en Nueva España: entre la utopía y la praxis. Los pueblos-hospital de Vasco de Quiroga [w:] Arte, cultura y poder en la Nueva España, ed. R.A. Rice, New York 2016, s. 18.

17 Ibidem, s. 20.

18 Quiroga znajdował się także pod wpływem chrześcijańskiego humanizmu Erazma z Rotterdamu oraz utopistów antycznych, Wergiliusza i Lukiana z Samosat - zob. A. Laird, The Classical Foundations of Utopia in Sixteenth Century Mexico: Lucian, Virgil, More and Vasco de Quiroga's Información en derecho (1535), „Comparatismes en Sorbonne” 2015, nr 6, s. 6, 9.

19 Zavala twierdzi, że Quiroga był pierwszym thumaczem fragmentów Utopii Morusa z łaciny na język hiszpański - zob. S. Zavala, Pensamiento y lecturas de Vasco de Quiroga [w:] Memoria del X Congreso Mundial Ordinario de Filosofia del Derecho y Filosofía Social, vol. 10, ed. J.L. Curie1, México 1984, s. 349-350. W całości na język hiszpański Utopia po raz pierwszy została przełożona przez F. de Queveda w 1637 r. Biskup Zumárraga posiadał wydanie Utopii z 1518 r., mające nieco inny tytuł niż wydanie z 1516 r.: De optimo reip. Statu, deque nova insula utopia, libellus vere aureus, nec minus salutaris quam festiuus, clarissimi disertissimique viri Thomae Mori inclytae civitatis londinensis civis \& vicecomitis; colophon: Basileae apvd Ioannem Frobenivm mense novembri an M.D.XVIII. Wszystkie podawane w przypisach odniesienia do De optimo reip. Statu dotyczą więc wydania z 1518 r. Egzemplarz De optimo reip. Statu Zumárragi znajduje się obecnie w Benson Latin American Collection, General Libraries, University of Texas at Austin (Benson Collection, LAC-ZZ Rare Books, GZZ 321.07 M813D 1518; local note: Benson (LAC-ZZ), Special collection; OCLC number: 12899667) - zob. P.S. Lietz, More's Utopia in America, „The Catholic Lawyer” 1956, vol. 2, no. 4, s. 343.

20 Wielu autorów podejmowało zagadnienie relacji między odkryciami geograficznymi a Utopia Morusa. Niektórzy jako jej źródło wskazują De orbe novo decades (1511) Pedra Mártira de Angleríi zob. S. Cro, La utopía cristiano-social en el Nuevo Mundo, „Anales de Literatura Hispanoamericana” 1978, no. 7, s. 93-97. Inni argumentują, że na Morusa miały wpływ opisy podróży Ameriga Vespucciego - zob. P. Borges, La inspiración americana de la Utopía de Tomás Moro, „Mar Oceana. Revista del Humanismo Español e Iberoamericano" 1995, no. 2, s. 97, 101; D. Ramos, Influencia de los descubrimientos en la ideología europea. El origen de „La Utopía”, como fruto del descubrimiento colombino, „Anales de Historia Contemporánea” 1991, vol. 8, s. 36-41; N. Poh1, Utopianism after More: The Renaissance and Enlightenment [w:] The Cambridge Companion to Utopian Literature, ed. G. Claeys, Cambridge 2010, s. 53. 
nie do przyjęcia było dla niego występujące w wizji Morusa i niepoddane przez niego krytyce niewolnictwo. Sprzeciw wobec niewolenia miejscowej ludności, poszanowanie autonomii indiańskich wspólnot oraz wolności jednostek był wszak głównym motywem działań Quirogi.

Według tego projektu w założonych przezeń osiedlach powinno mieszkać po 6000 „rodzin”; podstawę każdej z nich miało stanowić 10-16 żonatych mężczyzn, co wraz z ich krewnymi i najbliższymi dawałoby w sumie 60000 osób ${ }^{21}$. Wszyscy mieszkańcy tych osiedli zajmowaliby się rolnictwem i rzemiosłem ${ }^{22}$. Tak jak w Utopii Morusa dzień pracy miał tam trwać sześć godzin ${ }^{23}$, próżnowanie byłoby zabronione, a czas wolny wypełniałyby użyteczne, choć mniej pilne zajęcia (np. prace porządkowe ${ }^{24}$. Tak jak zakładał Morus, we wspólnotach Quirogi ziemia miała stanowić publiczną własnośćc ${ }^{25}$. Pracę na roli i hodowlę bydła nadzorowaliby ojcowie rodzin, w szczególności nie pozwalając na lenistwo. Owoce wspólnej pracy miały być gromadzone w magazynach, a następnie rozdzielane według potrzeb członków wspólnoty. Nadmiar przekazywano by starcom, wdowom, sierotom, chorym i kalekim ${ }^{26}$. Quiroga zalecał, aby konflikty rozwiązywano na miejscu, bez wnoszenia skarg do sądów, ze względu na wysokie koszty procesów oraz groźbę uwięzienia winnych, ale także dlatego, że mieszkańców republik powinny łączyć braterskie więzy ${ }^{27}$. Stąd też wynikał nakaz szacunku dla wszystkich oraz zakaz wyśmiewania osób źle odzianych, zdeformowanych, okaleczonych, inwalidów. W republikach Quirogi nie istniały więzienia, a osoby leniwe, pijaków i ludzi wywołujących skandale usuwano $\mathrm{z}$ nich ${ }^{28}$. Jedną $\mathrm{z}$ instytucji mających na celu wspólne dobro był szpital (w sensie węższym). Odzież wszystkich członków wspólnoty miała być prosta, wygodna, bez ozdób, jednakowej barwy, sporządzana przez samych jej użytkowników, by uniknąć wydatków na krawców, inna do pracy, a inna do przebywania w miejscach publicznych ${ }^{29}$.

21 V. de Quiroga, Información..., s. 201; resp. Th. More, op. cit., s. 72, 86. Według szacunków Gómeza oba miasteczka liczyły razem ok. 30000 mieszkańców - zob. F. Gómez, El régimen jurídico de utopía indiana: Vasco de Quiroga (1470-1565), „Anales del Museo de América” 1999, no. 7, s. 126. Inni autorzy twierdzą natomiast, że tylu mieszkańców liczyło samo miasteczko Santa Fe de México - zob. A.R. Rodríguez-Orozco, M.E. Rodríguez Pérez, Tipologías de arquitectura nosocomial a ambos lados del Atlántico, siglo XVI. El modelo de Enrique Egas en España y el de Vasco de Quiroga en Nueva España, „Gaceta Médica de México” 2013, vol. 149, no. 4, s. 465. Miasta założone przez Quirogę przetrwały do lat 70. XIX w. - zob. P. Serrano Gassent, Vasco de Quiroga. Utopía y derecho en la conquista de América, Madrid 2001, s. 229; G. García Ureña, Edad Áurea y res publica: en torno a las fuentes clásicas del utopismo de Vasco de Quiroga, „Res Publica. Revista de Historia de las Ideas Políticas" 2014, vol. 17, núm. 1, s. 20.

22 Resp. Th. More, op. cit., s. 79.

23 V. de Quiroga, Reglas y ordenanzas para el gobierno de los hospitales de Santa Fe de México y de Michoacán [w:] Don Vasco de Quiroga. Pensamiento jurídico, s. 224; resp. Th. More, op. cit., s. 80.

24 Resp. Th. More, op. cit., s. 81.

25 Resp. ibidem, s. 63, 156-157.

26 Resp. ibidem, s. 87-89.

27 V. de Quiroga, Reglas..., 236.

28 Ibidem, s. 238.

29 Ibidem, s. 232-233; resp. Th. More, op. cit., s. 79-80. 
Reglas... ujawniają także troskę o życie rodzinne, między innymi nakazując rodzicom dbać o ożenek i zamążpójście ich potomstwa w odpowiednim wieku (dla chłopców było to 14 lat, dla dziewczyn - 12) z osobami będącymi członkami społeczności tej samej republiki. Dzieci miały się uczyć i dwa razy w tygodniu po skróconych lekcjach zdobywać doświadczenie w pracach rolniczych, w formie trwającej dwie godziny radosnej rozrywki ${ }^{30}$. Część rodzin, zaopatrzona w odpowiednie narzędzia, miała przebywać poza miastem, przez dwa lata mieszkając wśród uprawianych przez nie pól ${ }^{31}$.

Wspólnoty założone przez Quirogę były zarządzane przez wybieraną spośród ich mieszkańców w tajnym głosowaniu, „bez emocji i afektów”, radę (z wyjątkiem jej przewodniczącego, który powinien być Hiszpanem powołanym na to stanowisko dekretem administracji królewskiej) ${ }^{32}$, sędziów, głównego administratora oraz zarządców dzielnic. Wszyscy ci urzędnicy zobowiązani byli zbierać się co trzy dni, by omawiać sprawy republiki i podejmować decyzje. Wolna elekcja miała dotyczyć także wyboru „ojców rodzin” na sześcioletnią kadencję (w Información... Quiroga wspomina także o „matkach rodzin”). „Ojcem rodziny” mógł zostać mężczyzna będący „dobrym chrześcijaninem oraz człowiekiem dobrego życia, obyczajów i dobrego przykładu" "33.

Quiroga uznawał za rzecz fundamentalnie ważną ustanowienie takiej formy republiki, którą określał mianem policía mixta ${ }^{34}$. Podkreślał, że dobry projekt życia społecznego powinien uwzględniać różne sfery ludzkich potrzeb i aktywności - ekonomiczne $i$ administracyjne, a także po chrześcijańsku rozumiane aspiracje duchowe. Oba aspekty tego ustroju były ściśle ze sobą związane, niemniej jego domena duchowa miała charakter podstawowy.

Skalę i wartość dokonań Quirogi można ocenić jedynie w kontekście dokonujących się w Ameryce Łacińskiej przemian historycznych i społecznych jego epoki, dlatego niżej szkicujemy ich zarys. Zwracamy uwagę zwłaszcza na te procesy i kwestie, które stanowiły przedmiot najwyższej troski hiszpańskiego reformatora: na proces reorganizacji życia społeczno-ekonomicznego miejscowej ludności oraz na zagadnienie jej statusu prawno-politycznego w relacjach z hiszpańską Koroną.

\section{HISTORYCZNO-SPOŁECZNY KONTEKST DZIEŁA VASCO DE QUIROGI}

W pierwszych dziesięcioleciach po podboju Nowego Świata hiszpańska polityka dotycząca społecznej organizacji jego rdzennych mieszkańców nie była jednoznacznie określona, niemniej w tej kwestii wyodrębniały się trzy zasadnicze kierunki

\footnotetext{
30 Resp. Th. More, op. cit., s. 79, 101.

31 V. de Quiroga, Reglas..., s. 229; resp. Th. More, op. cit., s. 72-73.

32 V. de Quiroga, Reglas..., s. 202; resp. Th. More, op. cit., s. 78.

33 V. de Quiroga, Reglas..., s. 234.

34 Idem, Información..., s. 108, 173-179, 196, 201-202, 206-207.
} 
myślenia. Pierwszy przewidywał całkowite zniszczenie miejscowych struktur społecznych i politycznych oraz narzucenie miejscowej ludności rozwiązań hiszpańskich, drugi zakładał respektowanie zastanej organizacji społecznej, trzeci - utworzenie wydzielonych republik indiańskich, mających swoje władze i zarządzanych według ich własnych zasad. Zwolennikiem tego ostatniego rozwiązania był między innymi Bartolomé de las Casas, który przedstawił tę ideę na madryckim dworze w $1515 \mathrm{roku}^{35}$. Hiszpańska polityka miała wkrótce przyjąć ten właśnie kierunek.

Pierwszą próbę utworzenia indiańskich miast (republik) podjęli w latach 15171519 hieronimici na Españoli ${ }^{36}$. Ich projekt powstał w obliczu realnej możliwości wymarcia mieszkańców wyspy - nie tylko z powodu ciężkiej pracy, do jakiej zmusili ich kolonialiści, ale także dlatego, że oddzielili oni mężczyzn od kobiet, zabierając ich do pracy w kopalniach, co skutkowało drastycznym spadkiem liczby narodzin. Zakonnicy planowali utworzenie 30 miasteczek, ale z powodu epidemii, która zabiła trzy czwarte populacji wyspy, zorganizowali ich 17. Pozostali przy życiu niechętnie opuszczali swoje rodzinne strony, by zamieszkać w nowych miejscach, a ponadto majordomowie zarządzający miasteczkami obchodzili się z nimi niegodziwie, dbając przede wszystkim o własne zyski. Projekt ten szybko więc upadł, a Indian ponownie rozdzielono między encomenderos ${ }^{37}$.

W 1538 roku, kilkanaście lat po tym eksperymencie i kilka lat po założeniu republik-szpitali przez Quirogę, władze hiszpańskiej Korony wydały rozporządzenie, by Indianie zostali poddani - bez stosowania przymusu - społecznej organizacji. Podjęte wówczas na masową skalę działania polegały na koncentracji rozproszonej ludności w nowo zakładanych miastach bądź też w dawnych ośrodkach miejskich, zwykle radykalnie przebudowywanych na wzór europejski. W Ameryce Środkowej nazywano je najczęściej kongregacjami, w innych regionach - redukcjami oraz juntami ${ }^{38}$.

35 Th. Hillerkuss, La República en los pueblos de indios de la Nueva Galicia en el siglo XVI, „Anuario Saber Novohispano” 1995, s. 243.

${ }^{36}$ Zob. E. Mira Caballos, La primera utopía americana: las reducciones de indios de los jerónimos en La Española (1517-1519), „Jahrbuch für Geschichte Lateinamerikas” 2002, vol. 39, s. 17.

37 W 1496 r. ludność wyspy liczyła 3,7 mln rdzennych mieszkańców, w 1508 r. było ich ok. 92000 , w 1518 r. - ok. 15 500, a w 1570 r. - już tylko 125 osób - zob. M. del Refugio Cabrera Vargas, El indio en las Relaciones Geográficas del siglo XVI [w:] Diversidad étnica y conflicto en América Latina. El indio como metáfora en la identidad nacional, t. 2, eds. R. Barceló, M.A. Portal, M.J. Sánchez, México 2000, s. 18.

38 Najbardziej znane przedsięwzięcie tego rodzaju podjęto w prowincjach Guayará, Itatim i Paraná, należących dzisiaj do Brazylii, Paragwaju i Argentyny. W 1580 r. na tych terenach rozpoczęli swoją działalność misyjną franciszkanie, ale nie udało się im uniezależnić Indian od systemu kolonialnego, ponieważ założone przez nich ośrodki misyjne miały charakter otwarty, były położone blisko miast, podatne na ingerencję kolonizatorów, łącznie z braniem przez nich w niewolę ludności, wśród której pracowali franciszkanie. W 1553 r. została tam ustanowiona Provincia Jesuítica del Paraguay. Poczynając od 1609 r., jezuici założyli na terenach nieskolonizowanych, będących jednak własnością Korony hiszpańskiej, federację 30 autonomicznych osiedli zwanych redukcjami. Zostały one zorganizowane w celu ochrony wolności, godności i odpowiedzialności Indian. Z tego względu bywają one nazywane „utopią wewnątrz systemu kolonialnego". Rekrutacja do redukcji odbywała się bez przemocy. Głównym czynnikiem, który decydował o wyborze miejsca, w jakich te osiedla zakładano, była możliwość uniknięcia kontaktów z Hiszpanami i Portugalczykami oraz ustrzeżenia się przed ich zakusami wykorzystania Indian do pracy 
Działania te przeprowadzono w dwóch fazach: pierwsza trwała w latach 1550-1564, druga w latach $1593-1605^{39}$. Peter Gerhard, wskazując na motywy przeprowadzenia tego przedsięwzięcia, pisze: „Hiszpanie szybko zdali sobie sprawę, że ani nie będą mogli w pełni eksploatować, ani efektywnie katechizować ludu rozproszonego po odległych terenach, gdzie będzie on unikał płacenia trybutu i praktykował zakazane rytuały" ${ }^{\prime 4}$. Ponadto, po epidemii z lat 1545-1548, liczba miejscowej ludności tak bardzo spadła, że pozostali przy życiu nie mogli skutecznie uprawiać swych ziem. Gerhard jednak zaznacza, że chciwość nie stanowiła głównego motywu, jakim kierowali się Hiszpanie, tworząc kongregacje; miało nim być „niemal jednomyślne przeświadczenie władz cywilnych i kościelnych, że jest złe dla ludzi żyć w rozproszeniu" ${ }^{\prime 1}$.

Utworzone w pierwszej fazie kongregacje miały strukturę zwaną hybrydową, składającą się z głównego miasta (cabecera) i podległych mu administracyjnie osiedli pozamiejskich (estancias). W powstających w Nowym Świecie miastach, na wzór miast Hiszpanii, w których dzielnice żydowskie i muzułmańskie były odseparowane od kastylijskich, wydzielono kwartały Hiszpanów (gente de razón) i Indian, lecz (tak jak w wypadku miasta Meksyku) zarządy miast (cabildos) miewały także charakter interetniczny ${ }^{42}$. Większość kongregacji zyskała status „republik”, to znaczy zarządzali nimi urzędnicy wybierani przez mieszkańców, posiadały one swoje ziemie, lasy, wody i inne tego rodzaju dobra. Zakładając kongregacje, Hiszpanie byli zobligowani prawem do respektowania istniejącej przed konkwistą struktury politycznej i społecznej Indian oraz dotychczasowego systemu własności ziemi ${ }^{43}$.

System ten został wprowadzony w zbliżonych formach na tych terenach podległych hiszpańskiej administracji, które charakteryzowały się wysokim poziomem rozwoju cywilizacyjnego i kulturalnego $0^{44}$. Sprzyjająca jego utworzeniu okazała

w encomiendas. W $1633 \mathrm{r}$. Indianie przebywający w redukcjach zostali rozporządzeniem królewskim uwolnieni od pracy w majątkach białych, a 30 lat później uznani za poddanych Korony hiszpańskiej. Rady miejskie tych osiedli były wybierane przez samych Indian. Redukcje miały racjonalnie zorganizowany podział pracy i dochodów; m.in. obowiązki przydzielano odpowiednio do zdolności i umiejętności pracujących. Pracowali wszyscy, poza chorymi, nielicznymi urzędnikami miejskimi oraz dziećmi. Cały ten system został skonsolidowany w latach 1640-1680 i trwał, mimo rozwiązania Towarzystwa Jezusowego w XVIII w., do połowy XIX stulecia.

39 Zob. P. Gerhard, Congregaciones de indios en la Nueva España antes de 1570, „Historia Mexicana" 1977, vol. 26, no. 3, s. 347. Ta faza kongregacji bywa także datowana nieco inaczej; wskazuje się np. okresy między latami 1595 i 1606 lub 1580 i 1610.

40 Ibidem, s. 349.

${ }^{41}$ Ibidem, s. 385; zob. B. García Martínez, Ideas y leyes sobre poblamiento en el México colonial: la acción del gobierno [w:] El poblamiento de México. Una visión histórico-demográfica, t. 2: El México colonial, ed. A. Arenzana, México 1993, s. 174.

42 Zob. R. Rovira Morgado, ,, Se ha de suplicar que los regimientos de esta ciudad sean veinticuatrías": El cabildo de Granada como propuesta institucional interétnica en la temprana república de la ciudad de México, „Estudios de Historia Novohispana” 2016, no. 55, s. 81-83.

${ }_{43}$ Zob. Recopilación de las Leyes de los Reinos de las Indias, Libro VI, Tít. III, Ley IX; F. Castro Gutiérrez, El origen y conformación de los barrios de indios [w:] Los indios y las ciudades de Nueva España, ed. F. Castro Gutiérrez, México 2010, s. 118-119.

44 F. Durán Sandoval, Pueblos de indios y acceso a la tierra en San Luis Potosí, 1591-1767, „Revista Historia y Justicia” 2015, no. 5, s. 10. 
się silna struktura hierarchiczna tych społeczeństw, których elity polityczne podjęły współpracę z kolonizatorami; dzięki takiej kooperacji udawało się ten porządek wprowadzać w miarę pokojowo. Wśród społeczności o słabiej zhierarchizowanej strukturze ważniejszy bywał przymus, chociaż ze względu na skromne zasoby środków represji, jakimi dysponowali Hiszpanie w Nowym Świecie, nie stosowano go powszechnie. W drugiej fazie kongregacji mieszkańcy osiedli pozamiejskich zostali przeniesieni do miast, a niektóre miasta zostały połączone w większe ośrodki; kongregacje te były wymuszone i obowiązkowe ${ }^{45}$.

Przenosząc miejscową ludność do miast, hiszpańskie władze kolonialne starały się zachować jej tradycyjny system przywództwa, mianując na gubernatorów i burmistrzów dotychczasowych naczelników, początkowo nazywanych przez Hiszpanów „naturalnymi panami” (señores naturales), a od 1538 roku „kacykami”. W Nowej Hiszpanii potomkowie azteckiej arystokracji zostali szybko uznani przez hiszpańską Koronę za szlachtę (co pociągało za sobą m.in. zwolnienie ich z płacenia podatków, przyznanie prawa do noszenia broni i dosiadania konia); niektórzy z nich stali się nawet encomenderos i weszli w koligacje matrymonialne z rodzinami konkwistadorów. Potomkowie azteckich rodów sprawowali bezpośrednią kontrolę nad strukturami społecznymi, które przetrwały konkwistę, a także od pierwszych dekad okresu kolonialnego występowali w obronie interesów podległej im ludności, na przykład angażując się w spory prawne z przedstawicielami porządku kolonialnego ${ }^{46}$. Najważniejszym stanowiskiem w tym nowym systemie administracji, o które mogli się ubiegać señores naturales, była funkcja gubernatora. Kacyk, który je zajmował, utrzymywał - a niekiedy nawet umacniał - swoją dotychczasową społeczną, polityczną i ekonomiczną pozycję ${ }^{47}$. Obecna w życiu politycznym miast powstałych w wyniku kongregacji prekolumbijska arystokracja ,utrzymała dawny system administracyjny, kontrolę nad terytorium i ręce do pracy" 48 .

Kolejnym ważnym zagadnieniem, które w szczególności niepokoiło Quirogę, była kwestia statusu prawnego rdzennych mieszkańców podbitych przez Hiszpanię terytoriów Nowego Świata - ich praw obywatelskich i, nade wszystko, ich wolności. Podejmując to zagadnienie, należy najpierw zauważyć, że w Europie w epoce poprzedzającej konkwistę niewolnictwo miało mocną legitymizację teoretyczną i prawną: akceptowali je filozofowie greccy, sankcjonowało je prawo rzymskie, aprobowali je autorzy Starego i Nowego Testamentu, ojcowie Kościoła oraz teologowie chrześcijańscy. Kwestia prawomocności brania w niewolę Indian pojawiła się niemal w momencie odkrycia Nowego Świata. Nim została ona poddana pod dyskusję

45 Zob. F.L. Jiménez Abollado, Valor etnográfico de las congregaciones civiles de pueblos de indios: la congregación de San Francisco Temango, 1598-1605, „Revista Española de Antropología Americana" 2009, vol. 39, núm. 2, s. 44.

46 Zob. S. Álvarez, El pueblo de indios en la frontera septentrional novohispana, „Relaciones. Estudios de Historia y Sociedad” 2003, vol. 24, núm. 95, s. 115-116; F. Du rán Sandoval, op. cit., s. 8.

47 P. Cruz Pazos, Cabildos y cacicazgos: alianza y confrontación en los pueblos de indios novohispanos, „Revista Española de Antropología Americana” 2004, vol. 34, s. 155.

48 T. Jalpa Flores, La construcción de los nuevos asentamientos en el ámbito rural: el caso de las cabeceras de la provincia de Chalco durante los siglos XVI y XVII, „Estudios de Historia Novohispana” 2008, no. 39, s. 24; S. Álvarez, op. cit., s. 116. 
i rozwiązana, niewolnictwo było praktykowane, a do tych, którzy tę praktykę zapoczątkowali, należał sam Kolumb, który sprowadził do Hiszpanii kilkuset Indian. Za pozwoleniem Monarchów Katolickich 12 kwietnia 1495 roku zaczęto ich sprzedawać na rynku w Sewilli, ale cztery dni później sprzedaż zawieszono ze względu na wątpliwości władców, prawników i teologów co do moralnej i prawnej zasadności tej praktyki ${ }^{49}$. Od tego czasu kwestia wolności Indian była w Hiszpanii szeroko dyskutowana przez profesorów teologii i prawa, urzędników administracji królewskiej oraz ekspertów zapraszanych przez monarchów do udziału w organizowanych przez nich w tym celu debatach. Problem, jaki usiłowano rozwiązać, wyrażał się w pytaniu o to, czy zgodne z prawem jest podejmowanie wojny przeciw Indianom i czy w związku z tym sprawiedliwe jest branie ich do niewoli. Brak jednoznacznego rozstrzygnięcia tej kwestii sprawiał, że również hiszpańskie prawodawstwo w odniesieniu do niej dość długo nie było konsekwentne. Jeszcze w latach 20. XVI stulecia prawo pozwalało wytoczyć Indianom wojnę i brać ich do niewoli, w wypadku gdy okazują nieposłuszeństwo przedstawicielom władzy królewskiej (tak stanowią np. rozporządzenia z 1523 roku: Instrucción a Diego de Velázquez oraz Instrucción a Hernán Cortés). Wprawdzie w Provisión para todas las islas y tierras descubiertas z 1530 roku pojawia się ogólny zakaz brania Indian do niewoli, ale Provisión z 1534 roku ponownie na to pozwala. W rozporządzeniach królewskich z lat 40 . XVI wieku stosunek do tej kwestii nadal nie był konsekwentny, niemniej przybierał bardziej zdecydowany kierunek. Przełomowe znaczenie miały Leyes y ordenanzas nuevamente hechas por su magestad para la gobernación de las Indias y buen tratamiento y conservación de los indios (powszechnie znane jako Leyes Nuevas) z 1542 roku, w których cesarz Karol V zabraniał brania do niewoli Indian i nakazywał, by natychmiast zostali uwolnieni wszyscy niewolnicy oraz by Indian traktowano jak wasali Korony (a zatem jak ludzi wolnych) ${ }^{50}$.

Istotne znaczenie dla uformowania się jednoznacznej postawy wobec wolności Indian miała dysputa w Valladolid, prowadzona w latach 1550-1551 przed Real Consejo de Indias. Jej głównymi protagonistami byli Bartolomé de Las Casas i Juan Ginés de Sepúlveda. Sepúlveda bronił tezy o prawie wyższej cywilizacji do podporządkowania sobie cywilizacji znajdujących się na niższym szczeblu rozwoju. Jego oponent, Las Casas, postulował wyzwolenie Indian spod władzy Hiszpanów, zaprzestanie ich eksploatacji i ucisku oraz prowadzenie ich chrystianizacji w sposób właściwy dla tej religii (tj. unikając przymusu) i sprawowanie nad nimi władzy także w sposób zgodny z religią chrześcijańską. Nie wykluczał on stosowania siły przez

49 Zob. M. Fazio, Descubrimiento de América: derecho natural y pensamiento utópico, „Acta Philosophica. Rivista Internazionale di Filosofia" 1992, vol. 1, no. 2, s. 218.

50 Zob. M. Menegus Bornemann, El gobierno de los indios en la Nueva España, siglo XVI. Señores o cabildo, „Revista de Indias” 1999, vol. 59, no. 217, s. 602-604; F. Durán Sandova1, op. cit., s. 13; M. Quiroga Zuluaga, Las políticas coloniales y la acción indígena: la configuración de los pueblos de indios de la provincia de Páez, siglos XVII y XVIII, „Anuario Colombiano de Historia Social y de la Cultura" 2015, vol. 42, no. 1, s. 26; R. Brambila Paz, Congregaciones del siglo XVI en Chapa de Mota, Estado de México, „Estudios de Cultura Otopame” 2008, vol. 6, no. 1, s. 53; B.P. Ow ensby, Pacto entre rey lejano y súbditos indigenas. Justicia, legalidad y política en Nueva España, siglo XVII, „Historia Mexicana” 2011, nr 62 (1), s. 90-91. 
władzę królewską, ale tylko w granicach prawa ${ }^{51}$. Real Consejo de Indias, uniwersytety w Salamance i w Alcalá oraz większa część filozofów, teologów i prawników hiszpańskich opowiedziała się za stanowiskiem B. de Las Casas, co znalazło wyraz w jednoznacznym ukierunkowaniu hiszpańskiego prawodawstwa w odniesieniu do rdzennej ludności Ameryki.

Z kwestią uznania rdzennych mieszkańców Nowego Świata za wasali Korony hiszpańskiej i ludzi wolnych wiąże się zagadnienie wykorzystywania ich jako siły roboczej przez hiszpańskich kolonizatorów. Nie ulega wątpliwości, że byli oni w ten sposób eksploatowani, warto jednak zauważyć, że kiedy Hiszpanie wkroczyli do Ameryki, spotkali się ze społeczeństwami, w których (jak np. w królestwie Azteków) większość ludności była eksploatowana jako siła robocza i płaciła trybuty swoim zwierzchnikom ${ }^{52}$ - podobnie jak w feudalnych społeczeństwach europejskich, opartych na wykorzystaniu chłopów ${ }^{53}$. A zatem, jak zauważa F. Kubiaczyk, w społeczeństwach Nowego Świata kontrola siły roboczej przez Hiszpanów „nie tylko nie była czymś nowym, ale wpisywała się w indiańską tradycję wykorzystywania przymusu pracy. Co więcej, niekiedy obowiązkowe świadczenia nakładane na tubylców przez kolonizatorów były mniej dotkliwe od tych, które obowiązywały w imperiach azteckim i inkaskim" 54 . Według Añoverosa Garcíi sytuacja pod tym względem pogorszyła się $\mathrm{w}$ społecznościach indiańskich $\mathrm{w}$ regionach położonych $\mathrm{w}$ pobliżu wielkich majątków ziemskich, większych miast czy kopalń, poprawiła się zaś w miejscach oddalonych od takich ośrodków. Zauważa on także, że eksploatacja siły roboczej osiągnęła wymiar niespotykany w całej historii ludów Nowego Świata w ostatnich trzech dziesięcioleciach XIX stulecia i pierwszych trzech dekadach wieku następnego, a więc już w okresie postkolonialnym. Znajdujący się wówczas u władzy liberałowie stworzyli takie warunki (prawne i pozaprawne), w których większość ziem należących do indiańskich wspólnot została przez nie definitywnie utracona na rzecz wielkiej własności ziemskiej, a siła robocza wydziedziczonych z własności jednostek i społeczności została poddana eksploatacji w prywatnych majątkach ziemskich i przedsiębiorstwach publicznych ${ }^{55}$.

51 Dokumenty stanowiące zapis debaty w Valladolid - zob. I. Krupecka, B. de Las Casas, J. Ginés de Sepúlveda, D. de Soto. Dysputa w Valladolid (1550/1551), Gdańsk 2014.

52 F. Kubiaczyk, Kontrola sity roboczej w gospodarce kolonialnej Ameryki hiszpańskiej: encomienda, repartimiento i niewolnictwo, „Studia Europaea Gnesnensia” 2011, nr 4, s. 18.

53 J.M. Añoveros García, La fuerza de trabajo del indigena americano en las épocas prehispánica y virreinal, „Quinto Centenario” 1982, vol. 3, s. 104.

${ }_{54}$ F. Kubiaczyk, op. cit., s. 16.

55 J.M. Añoveros García, op. cit., s. 107-108. 


\section{UWAGI KOŃCOWE: DZIAŁALNOŚĆ QUIROGI W PERSPEKTYWIE KRYTYKI POSTKOLONIALNEJ}

Wbrew wyżej naszkicowanemu obrazowi zmian w życiu społeczeństw Nowego Świata, jakie zaszły po jego podboju przez hiszpańskie imperium (przyznajemy dość optymistycznemu i pozytywnemu), niektórzy autorzy twierdzą, że proces kongregacji był dla nich szkodliwy, że radykalnie zmienił ekonomiczne podstawy ich życia, zniszczył wiele form relacji społecznych i politycznych istniejących w epoce prehiszpańskiej ${ }^{56}$. Szczególnie negatywnie tę przemianę oceniają uczeni prowadzący badania w nurcie studiów postkolonialnych, odwołujący się zwłaszcza do koncepcji kapitalistycznych technik dyscyplinowania Michela Foucaulta. W tej perspektywie jako bezpośredni cel reorganizacji autochtonicznych społeczeństw przez Hiszpanów jawi się ich polityczne podporządkowanie imperium, a w jego następstwie - zawłaszczenie ich bogactw naturalnych, eksploatacja siły roboczej, ukształtowanie homogenicznego systemu społeczno-rasowego, akulturacja oraz wytworzenie bezsilnych i biernych ,podmiotów kolonialnych" ${ }^{57}$.

Tego rodzaju tezom, a zwłaszcza stanowiącemu ich podstawę przekonaniu, że społeczeństwa indiańskie były pasywnym przedmiotem społecznego eksperymentu Hiszpanów, przeciwstawiają się badacze pozostający poza nurtem studiów postkolonialnych ${ }^{58}$. Zauważają oni, że chociaż utworzenie zwartych społeczności w przestrzeniach miejskich stanowiło dla miejscowej ludności nowość, to powstałe w wyniku kongregacji miasta i dzielnice indiańskie oferowały „,przestrzeń współżycia, decydowania o własnych sprawach, uczestniczenia w sprawowaniu władzy obywatelskiej i kościelnej, zarządzania wspólnymi dobrami" 59 . Spełniały one funkcję ośrodków formowania się nowych społeczeństw Ameryki Łacińskiej, stając się trwałą strukturą społecznego życia autochtonów, z którą identyfikują się oni do dzisiaj. Oczywiście byli oni zmuszani do sprzedaży swoich wyrobów po niekorzystnych cenach i do źle opłacanej pracy, obligowani do wypełniania licznych obowiązków podatkowych, doznawali przemocy i upokorzeń. Niemniej, jak staraliśmy się pokazać, hiszpańska Korona usiłowała chronić mieszkańców podbitych ziem, zrównując ich prawnie z jej europejskimi poddanymi w takich aspektach, jak wolność, własność, praca, władza i zachowanie struktury społecznej.

Wobec wzmiankowanych krytyk procesów społecznych, jakie dokonały się w Ameryce Łacińskiej pod wpływem hiszpańskich kolonizatorów, nie możemy się

56 Zob. E. de la Torre Vilar, Las congregaciones de los pueblos de indios. Fase terminal: aprobaciones y rectificaciones, México 1995, s. 64-65; F.L. Jiménez Abollado, op. cit., s. 55; B. García Martínez, op. cit., s. 171 i 183.

57 Zob. J. Sullivan, La congregación como tecnología disciplinaria en el siglo XVI, „Estudios de Historia Novohispana” 1996, vol. 16, s. 3, 36, 38-40; zob. R. Brambila Paz, op. cit., s. 54.

58 Zob. T. Jalpa Flores, op. cit., s. 18; B.P. Owensby, op. cit., s. 97.

59 F. Castro Gutiérrez, op. cit., s. 122; zob. D. Mundaca, Los pueblos-hospitales de Vasco de Quiroga, una sociedad racional, basada en un régimen de practices, „Tiempo y Espacio” 2013, núm. 30, s. 37 . 
spodziewać, by dzieło Quirogi wzbudzało jedynie szacunek. Tak oczywiście nie jest. Spotyka się ono także z zarzutami, które podkreślają zwłaszcza jego niedostateczny radykalizm. Na przykład Fernando Gómez zauważa, że pisma Quirogi (Quiroga’s repressive literature - jak je określa) nie zawierają bezpośredniej krytyki „ekspansywnej totalności imperialnego czy kolonialnego modelu państwa" i instytucjonalnie zorganizowanej zbrodniczości, że nawet w zasadzie nie odrzucają niewolnictwa. Według niego „eksperyment Quirogi należy rozumieć historycznie jako dogmatyczne żądanie prawnego (czy represyjnego) wszczepienia oficjalnej polityki rasowej" ${ }^{\prime \prime}$. Funkcjonujące w granicach legalizmu myśl i działania Quirogi cechować się miały represywnością $\mathrm{w}$ stosunku do autochtonó $\mathrm{w}^{61}$, a jego „oficjalna utopia zawsze promowała panowanie prawa kolonialnego" ${ }^{2}$. Autor postrzega „Quirogiański kolonialny utopizm” jako „wysiłek na rzecz odbudowania mocno nadwerężonych podstaw legalności kolonializmu" ${ }^{\prime 3}$.

Podobnie jak cytowany autor również José Aparecido Gomes Moreira, odnosząc się do projektu Quirogi, twierdzi, że była to:

koncepcja społeczeństwa „z punktu widzenia” samego konkwistadora, który decyduje o tym, jaki powinien być los podbitego. Lecz nie jest to projekt pomniejszający intensywną eksploatację materialną zasobów ludzkich i naturalnych [...]. Ani taki, który troskałby się choćby o racjonalność tej eksploatacji [...]. Jako chrześcijańskiemu humaniście, frasującemu się „zbawieniem dusz” i ,zachowaniem ziemi”, alternatywą „mniejszego zła”, jaka zdaje się pozostawać Quirodze, jest pogodzenie dwóch porządków, doczesnego i duchowego, w tym samym i jedynym projekcie kolonizacyjnym ${ }^{64}$.

Gomes Moreira suponuje także, że policía mixta Quirogi oznaczała dobre administrowanie, pacyfikujące opór Indian, a zatem politycznie korzystne dla hiszpańskiej Korony. Wskazuje on także na ograniczony zasięg i sprawczość zaleceń Quirogi, formułowanych w obronie wolności Indian, twierdząc, że należą one do „kolonialnego dyskursu chrześcijaństwa”, co wystarcza mu, by orzec, że był on „współtwórcą i usprawiedliwieniem niewolnictwa, które tak bardzo krytykuje" ${ }^{65}$. W jego przekonaniu idee i działania Quirogi nie były „,istotnie odmienne od tych, czy im przeciwstawne, które prowadzili tak zwani »osadnicy« hiszpańscy. W najlepszym razie chodziło o dwa modele konkwisty i kolonizacji”' ${ }^{\prime 6}$. Policía mixta Quirogi - twierdzi

60 F. Gómez, Experimentación social en los albores coloniales de la modernidad: el deseo utópico-reformista de Vasco de Quiroga (1470-1565), „Boletín Americanista”2000, no. 50, s. 103.

${ }_{61}$ Zob. F. Gómez, Good Places and Non-places in Colonial Mexico: The Figure of Vasco de Quiroga (1470-1565), Lanham-New York-Oxford 2001, s. 50-51, 72-73; F. Gómez, Experimentación..., s. 103-104. Autor pisze o „quirogiańskiej kulturze represywnej” oraz o „nowohiszpańskim represywnym reformizmie".

62 F. Gómez, Good Places..., s. 10.

63 Ibidem, s. 50.

64 J.A. Gomes Moreira, Conquista y conciencia cristiana: el pensamiento indigenista y jurídico teológico de Don Vasco de Quiroga (+1565), Quito 1992, s. 92. Według cytowanego autora Quiroga uznawał, że można przeciw Indianom prowadzić sprawiedliwą wojnę i brać ich do niewoli (s. 141-143 oraz 218). Jest to opinia niesprawiedliwa, ewidentnie wypaczająca myśl autora Información.

65 Ibidem, s. 218.

66 Ibidem, s. 220. 
Gomes Moreira - należy do projektu kolonialnego, mimo że nieco odmiennego od dominującego w Nowym Świecie, to znaczy tego, którego fundamentem był system niewolnictwa, niemniej natychmiast przypomina sobie, że ,jako funkcjonariusz Korony i biskup, Quiroga nie mógł planować utopii, która znajdowałaby się poza całym systemem kolonialnym"67.

Tezy zbliżone do przytoczonych znajdujemy także w pracy Jamesa Krippnera-Martíneza. Zauważa on, że Vasco de Quiroga miał nadzieję „ufundować swoje miasteczka-szpitale jako alternatywną strategię kolonizacji, taką, która wypełni obowiązek ewangelizacji i zapobiegnie ludobójstwu"68. Chociaż w następnym zdaniu dodaje: „był to cel chwalebny, biorąc pod uwagę możliwe alternatywy, jakie miała rdzenna ludność”, to jednak w kolejnym stwierdza: „nie powinniśmy żywić złudzeń co do jego intencji. Vasco de Quiroga w najmniejszym stopniu nie zamierzał podważać trwałości samych relacji kolonialnych" ${ }^{\circ 9}$. Co więcej, czytamy dalej, że wbrew poddaniu przez Quirogę radykalnej krytyce praktyki niewolenia Indian

jego sprzeciw wobec niewolnictwa był znacznie bardziej powściągliwy i ograniczony, niż się powszechnie uznaje. Nie sprzeciwiał się on samej instytucji niewolnictwa, lecz jedynie praktyce brania do niewoli ludności indiańskiej w konsekwencji „,wojny sprawiedliwej” bądź dlatego, że już jako znajdująca się w niewoli została ona „uratowana” (recused) przez jej nowych chrześcijańskich panów ${ }^{70}$.

Podane przykłady oceny myśli i działalności Quirogi należą do standardowych zarzutów, jakie kieruje część krytyków kolonializmu (podkreślmy: nie wszyscy) pod adresem tych, którzy w epoce konkwisty i kolonizacji Nowego Świata podejmowali reformatorskie działania zmierzające do poprawy sytuacji zniewolonych. Czytając prace owych krytyków, można dojść do wniosku, że największą winą obrońców godności i życia podbitych była ich przynależność do tej samej nacji, z której wywodzili się konkwistadorzy i kolonizatorzy. Zarzuty te są często obarczone błędem ahistoryzmu (czy też prezentyzmu), nie uwzględniają mentalności epoki, zwłaszcza w aspekcie odnoszącym się do niewolnictwa. Ponadto nie tylko nie biorą pod uwagę realnych możliwości sprawczych jednostki w obliczu imperium (czy mniej patetycznie - państwa), ale także, wychodząc od dogmatycznie przyjętych założeń, ignorują fakty. W wypadku myśli i działalności Quirogi nietrafność cytowanych zarzutów ujawnia nawet pobieżna lektura jego Información ..., będącej odważną krytyką założeń polityki kolonialnej hiszpańskiego państwa, pryncypialnie odmawiającą mu prawa do decydowania o wolności ludów zamieszkujących okupowane przez nie terytoria. Również ufundowanie przez Quirogę miast-szpitali, gdzie miała być chroniona wolność

67 Ibidem, s. 216.

68 J. Krippner-Martínez, Rereading the Conquest: Power, Politics, and the History of Early Colonial Michoacán, Mexico, 1521-1565, University Park, Pennsylvania, 2010, s. 86.

69 Ibidem.

70 Ibidem. Wcześniejszą swoją publikację (idem, Invoking ,,Tato Vasco”: Vasco de Quiroga, Eighteenth-Twentieth Centuries, „The Americas” 2000, vol. 56, no. 3, s. 1-28) autor ten poświęcił podważeniu reputacji Quirogi dominującej wśród badaczy, którzy podkreślają wysoką wartość jego teoretycznych i praktycznych dokonań. Uznał on tę opinię za mit zakorzeniony w dyskursie kolonialnym, naiwnie zinternalizowany także przez część rdzennej ludności Meksyku. 
Indian, powinno być postrzegane jako sprzeciw wobec niewolnictwa. Biorąc pod uwagę jego wypowiedzi i działania, nie można twierdzić, że był to projekt należący wyłącznie do ,imperialnego programu konkwisty i chrystianizacji”71. Tym bardziej imputowanie mu (co czynią niektórzy autorzy ${ }^{72}$ ), iż uzasadniał on możliwość prowadzenia sprawiedliwej wojny przeciw Indianom w celu ich chrystianizacji, należy uznać za dalekie od obiektywizmu fantazjowanie, będące przykładem przedkładania apriorycznie przyjętych założeń własnej teorii nad rozpoznanie czy uznanie faktów. Wydaje się ponadto, że przywoływani krytycy skłonni są uznać za wartościowe jedynie stanowiska rewolucyjne, wzdragają się natomiast przed uznaniem doniosłości opozycji mniej radykalnej - w perspektywie ich tez traci ona jakikolwiek sens, bo nie wyzwala z nędzy i opresji wszystkich i na zawsze. W istocie Vasco de Quiroga uratował przed niewolą i śmiercią niewielką grupę ludzi - taką, jaką mógł uratować jeden człowiek będący ponadto funkcjonariuszem systemu generującego opresję. Jest jednak oczywiste, że chociaż rewolucje radykalnie zmieniają rzeczywistość społeczną, to prowadzące do nich drogi miewają skromne początki. Wrażliwość na krzywdę i prosty, praktyczny zamysł Quirogi (oraz odczuwających i myślących podobnie jak on) były na początku jednej z takich dróg, dzięki którym jego myśli i dzieła możemy osądzać nawet tak, jak czynią to wyżej cytowani krytycy hiszpańskiego reformatora.

\section{BIBLIOGRAFIA}

Abarca Pérez A.J., Hospital-pueblo, expresión concreta del humanismo quiroguiano [w:] Memoria. XVIII Encuentro Nacional de Investigadores del Pensamiento Novohispano. Filosofía y pensamiento político, ed. A. Sánchez Flores, San Luis Potosi 2005, s. 556566.

Álvarez Morán J.C., De utopía a topía: la obra de don Vasco de Quiroga en la Nueva España, „Diario de Campo” 2011, nr 3, s. 59-64.

Álvarez S., El pueblo de indios en la frontera septentrional novohispana, „Relaciones. Estudios de Historia y Sociedad” 2003, vol. 24, núm. 95, s. 115-164.

Añoveros García J.M., La fuerza de trabajo del indígena americano en las épocas prehispánica y virreinal, „Quinto Centenario” 1982, vol. 3, s. 87-108.

Borges P., La inspiración americana de la Utopía de Tomás Moro, „Mar Oceana. Revista del Humanismo Español e Iberoamericano" 1995, no. 2, s. 91-111.

Brambila Paz R., Congregaciones del siglo XVI en Chapa de Mota, Estado de México, „Estudios de Cultura Otopame” 2008, vol. 6, no. 1, s. 35-57.

Camacho Rojo J.M., Fuentes González P.P., El mito clásico en los historiadores de Indias [w:] Homenaje a la Profesora María Luisa Picklesimer (In memoriam), eds. M.N. Muñoz Martín, J.A. Sánchez, Coimbra 2012, s. 41-67.

Cantú F., América y utopía en el siglo XVI, „Cuadernos de la Historia Moderna. Anejos” 2002, nr 1, s. 45-64.

${ }^{71}$ G. García Ureña, op. cit., s. 18-19.

72 Ibidem, s. 29. 
Castro Gutiérrez F., El origen y conformación de los barrios de indios [w:] Los indios y las ciudades de Nueva España, ed. F. Castro Gutiérrez, México 2010, s. 105-122.

Cro S., La utopía cristiano-social en el Nuevo Mundo, „Anales de Literatura Hispanoamericana" 1978, no. 7, s. 87-130.

Cruz Pazos P., Cabildos y cacicazgos: alianza y confrontación en los pueblos de indios novohispanos, „Revista Española de Antropología Americana” 2004, vol. 34, s. 149-162.

D'Anghiera P.M., De orbe novo, the Eight Decades of Peter Martyr d'Anghera, vol. 1, New York-London 1912.

Durán Sandoval F., Pueblos de indios y acceso a la tierra en San Luis Potosí, 1591-1767, „Revista Historia y Justicia” 2015, no. 5, s. 6-36.

Fazio M., Descubrimiento de América: derecho natural y pensamiento utópico, „Acta Philosophica. Rivista Internazionale di Filosofia” 1992, vol. 1, no. 2, s. 15-232.

García Martínez B., Ideas y leyes sobre poblamiento en el México colonial: la acción del gobierno [w:] El poblamiento de México. Una visión histórico-demográfica, t. 2: El México colonial, ed. A. Arenzana, México 1993, s. 170-186.

García Ureña G., Edad Áurea y res publica: en torno a las fuentes clásicas del utopismo de Vasco de Quiroga, „Res Publica. Revista de Historia de las Ideas Políticas” 2014, vol. 17, núm. 1, s. 11-31.

Gerhard P., Congregaciones de indios en la Nueva España antes de 1570, „Historia Mexicana" 1977, vol. 26, no. 3, s. 347-395.

Gomes Moreira J.A., Conquista y conciencia cristiana: el pensamiento indigenista y jurídico teológico de Don Vasco de Quiroga (+1565), Quito 1992.

Gómez F., Experimentación social en los albores coloniales de la modernidad: el deseo utópico-reformista de Vasco de Quiroga (1470-1565), „Boletín Americanista” 2000, no. 50, s. 101-121.

Gómez F., Good Places and Non-places in Colonial Mexico: The Figure of Vasco de Quiroga (1470-1565), Lanham-New York-Oxford 2001.

Gómez F., El régimen jurídico de utopía indiana: Vasco de Quiroga (1470-1565), „Anales del Museo de América" 1999, no. 7, s. 125-140.

Hillerkuss Th., La República en los pueblos de indios de la Nueva Galicia en el siglo XVI, „Anuario Saber Novohispano” 1995, s. 241-258.

Jalpa Flores T., La construcción de los nuevos asentamientos en el ámbito rural: el caso de las cabeceras de la provincia de Chalco durante los siglos XVI y XVII, „Estudios de Historia Novohispana" 2008, no. 39, s. 17-42.

Jiménez Abollado F.L., Valor etnográfico de las congregaciones civiles de pueblos de indios: la congregación de San Francisco Temango, 1598-1605, „Revista Española de Antropología Americana" 2009, vol. 39, núm. 2, s. 41-58.

Krippner-Martínez J., Invoking „,Tato Vasco”: Vasco de Quiroga, Eighteenth-Twentieth Centuries, „The Americas” 2000, vol. 56, no. 3, s. 1-28.

Krippner-Martínez J., Rereading the Conquest: Power, Politics, and the History of Early Colonial Michoacán, Mexico, 1521-1565, University Park, Pennsylvania 2010.

Krupecka I., B. de Las Casas, J. Ginés de Sepúlveda, D. de Soto. Dysputa w Valladolid (1550/1551), Gdańsk 2014.

Kubiaczyk F., Kontrola sity roboczej w gospodarce kolonialnej Ameryki hiszpańskiej: encomienda, repartimiento i niewolnictwo, „Studia Europaea Gnesnensia” 2011, nr 4, s. 9-44.

Laird A., The Classical Foundations of Utopia in Sixteenth Century Mexico: Lucian, Virgil, More and Vasco de A. Quiroga's Información en derecho (1535), „Comparatismes en Sorbonne" 2015, nr 6, s. 1-9. 
Lietz P.S., More's Utopia in America, „The Catholic Lawyer” 1956, vol. 2, no. 4, s. 340-349. Menegus Bornemann M., El gobierno de los indios en la Nueva España, siglo XVI. Señores o cabildo, „Revista de Indias” 1999, vol. 59, no. 217, s. 599-617.

Mira Caballos E., La primera utopía americana: las reducciones de indios de los jerónimos en La Española (1517-1519), „Jahrbuch für Geschichte Lateinamerikas” 2002, vol. 39, s. 9-35.

More Th., De optimo reip. Statu, deque nova insula utopia, libellus vere aureus, nec minus salutaris quam festiuus, clarissimi disertissimique viri Thomae Mori inclytae civitatis londinensis civis \& vicecomitis, Basileae apvd Ioannem Frobenivm mense novembri an M.D.XVIII.

Mundaca D., Los pueblos-hospitales de Vasco de Quiroga, una sociedad racional, basada en un régimen de practices, „Tiempo y Espacio” 2013, núm. 30, s. 23-64.

Owensby B.P., Pacto entre rey lejano y súbditos indígenas. Justicia, legalidad y política en Nueva España, siglo XVII, „Historia Mexicana” 2011, nr 62 (1), s. 59-106.

Paniótova T.S., Orígenes clásicos y autóctonos de la utopía en América Latina, „Revista Iberoamericana de Autogestión y Acción Comunal" 2012, no. 60, s. 147-162.

Pizarro Gómez F.J., La fundación de hospitales en Nueva España: entre la utopía y la praxis. Los pueblos-hospital de Vasco de Quiroga [w:] Arte, cultura y poder en la Nueva España, ed. R.A. Rice, New York 2016, s. 15-27.

Pohl N., Utopianism after More: The Renaissance and Enlightenment [w:] The Cambridge Companion to Utopian Literature, ed. G. Claeys, Cambridge 2010, s. 51-78.

Quiroga V. de, Carta al Consejo del licenciado Quiroga [w:] Don Vasco de Quiroga. Pensamiento jurídico. Antología, eds. R. Aguayo Spencer, J.L. Soberanes, México 1986, s. 74-80.

Quiroga V. de, Información en derecho del licenciado Quiroga sobre algunas provisiones del Real Consejo de Indias [w:] Don Vasco de Quiroga. Pensamiento jurídico. Antología, eds. R. Aguayo Spencer, J.L. Soberanes, México 1986, s. 83-212.

Quiroga V. de, Reglas y ordenanzas para el gobierno de los hospitales de Santa Fe de México y de Michoacán [w:] Don Vasco de Quiroga. Pensamiento jurídico. Antología, eds. R. Aguayo Spencer, J.L. Soberanes, México 1986, s. 220-240.

Quiroga Zuluaga M., Las políticas coloniales y la acción indígena: la configuración de los pueblos de indios de la provincia de Páez, siglos XVII y XVIII, „Anuario Colombiano de Historia Social y de la Cultura" 2015, vol. 42, no. 1, s. 23-50.

Ramos D., Influencia de los descubrimientos en la ideología europea. El origen de „La Utopía”, como fruto del descubrimiento colombino, „Anales de Historia Contemporánea” 1991, nr 8, s. 27-43.

Refugio Cabrera Vargas M. del, El indio en las Relaciones Geográficas del siglo XVI [w:] Diversidad étnica y conflicto en América Latina. El indio como metáfora en la identidad nacional, t. 2, eds. R. Barceló, M.A. Portal, M.J. Sánchez, México 2000, s. 11-46.

Rodríguez-Orozco A.R., Rodríguez Pérez M.E., Tipologías de arquitectura nosocomial a ambos lados del Atlántico, siglo XVI. El modelo de Enrique Egas en España y el de Vasco de Quiroga en Nueva España, „Gaceta Médica de México” 2013, vol. 149, núm. 4, S. 462-469.

Rovira Morgado R., ,, Se ha de suplicar que los regimientos de esta ciudad sean veinticuatrías": El cabildo de Granada como propuesta institucional interétnica en la temprana república de la ciudad de México, „Estudios de Historia Novohispana” 2016, no. 55, s. 80-98. 
Serrano Gassent P., Vasco de Quiroga. Utopía y derecho en la conquista de América, Madrid 2001.

Sullivan J., La congregación como tecnología disciplinaria en el siglo XVI, „Estudios de Historia Novohispana" 1996, nr 16, s. 33-55.

Torre Rangel J.A. de la, Tradición hispanoamericana de los derechos humanos. El aporte de dos jueces: Quiroga y Zorita [w:] Memoria. XVIII Encuentro Nacional de Investigadores del Pensamiento Novohispano. Filosofía y pensamiento político, ed. A. Sánchez Flores, San Luis Potosi 2005, s. 638-673.

Torre Vilar E. de la, Las congregaciones de los pueblos de indios. Fase terminal: aprobaciones y rectificaciones, México 1995.

Zavala S., Pensamiento y lecturas de Vasco de Quiroga [w:] Memoria del X Congreso Mundial Ordinario de Filosofía del Derecho y Filosofía Social, vol. 10, ed. J.L. Curiel, México 1984, s. 140-150. 